\title{
LITERATURA SURDA: CATEGORIZANDO AS PRODUÇÕES DIGITAIS DE TEXTOS RELIGIOSOS EM LITERÁRIOS E INFORMATIVOS \\ $* * *$
}

\section{DEAF LITERATURE: CATEGORIZING DIGITAL PRODUCTIONS OF RELIGIOUS TEXTS INTO LITERARY AND INFORMATIVE}

Carolina Silva Resende da Nóbrega ${ }^{1}$

\author{
Recebimento do texto: $18 / 04 / 2018$ \\ Data de aceite: 15/05/2018
}

RESUMO: O presente artigo aborda a identificação de texto religiosos em Libras. A base da pesquisa se respalda nos teóricos da Literatura Surda e Categorização como Peters (2000), Sutton-Spence (2005), Mourão (2016), e Edgar-Hunt (2013), entre outros. A investigação apresenta análises de vídeos em Libras, além disso apresenta questionário com um dos doze surdos evangélicos de diversas regiões do Brasil. É preciso levantar questões de uso do texto religioso: Quais são as categorias necessárias para os textos sagrados? Há possibilidade de a pessoa surda compreender o texto religioso em Libras sem o uso do português? São essas questões que nos levam a realizar pesquisas as quais abordam categorias organizadas. Seu objetivo é apresentar analises e categorias de produções digitais dos textos religiosos; destacar os textos religiosos categorizados para os tipos de textos Literários e Informativos em Libras. Por fim, espera-se que os textos religiosos em Libras possam ser categorizados e inseridos na Literatura Surda.

PALAVRAS-CHAVE: Literatura Surda; categorização; texto religioso Literário e Informativo.

ABSTRACT: This article addresses the identification of religious text in Libras. The basis of the research is supported by the theorists of Deaf Literature and Categorization such as Peters (2000), Sutton-Spence (2005), Mourão (2016), and Edgar-Hunt (2013) among others. The research presents video analysis in Libras, and also presents a questionnaire with one of the twelve deaf evangelicals from different regions of Brazil. It is necessary to raise questions of use of the religious text: What are the categories necessary for the sacred texts? Is it possible for the deaf person to understand the religious text in Libras without the use of Portuguese? It is these issues that lead us to conduct research that addresses organized categories. Its objective is to present analyzes and categories of digital productions of religious texts; highlight the religious texts categorized for the types of Literary and Informative texts in Libras. Finally, it is expected that the religious texts in Libras can be categorized and inserted in the Deaf Literature.

KEYWORDS: Deaf Literature; categorization; Literary and Informative religious text.

${ }^{1}$ Professora adjunta da Universidade Federal da Paraíba - UFPB, João Pessoa - Paraíba. E-mail: profcarolinanobrega@gmail.com

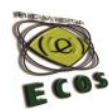




\section{Introdução}

$\mathrm{O}$ artigo foi baseado pela curiosidade com os textos religiosos através do uso da Libras sob vários aspectos. Existem produções de textos que vai de elementos narrativos até a encenação teatral com seus trajes específicos de diferentes épocas e de entidades religiosas. Nesse sentido, é importante ressaltar que esses textos sinalizados não eram registrados em vídeo; mas, com os avanços tecnológicos, nos dias atuais, esse registro acontece de fato. Dessa forma, é garantido o corpus da pesquisa, de modo a mostrar como seria a tradução da Bíblia com seus traços característicos, os trabalhos devocionais e seus estilos para com a comunidade surda.

Ao deparar sobre os textos realizados, surge questões que norteiam a pesquisa: quais são as estratégias visuais necessárias para uma boa tradução dos textos sagrados? Por que essas estratégias são utilizadas e em que momentos do texto? Por que, em alguns textos, há uma pessoa traduzindo de terno e gravata e fundo neutro, enquanto, em outros, existem elementos como cenário e figurinos? Por meio desses questionamentos, é que o artigo pretende analisar e categorizar as produções digitais dos textos religiosos e destaca os textos religiosos categorizados para os tipos de textos Literários e Informativos em Libras. A pesquisa partirá de uma análise comparativa de textos religiosos em Libras, ressaltando-se o fato de que, antigamente, não havia registros dessas produções textuais em Língua de Sinais aqui no Brasil. Com base nessa realidade, seria possível constatar as diferentes estratégias visuais que alteram a compreensão do conteúdo religioso. 
Esta pesquisa, inicialmente, tem como base teórica os estudos da Literatura Surda realizados e aborda diferentes perspectivas linguísticas entre a comunidade surda e a comunidade ouvinte com suas apresentações e suas tradições textuais, ao produzir uma nova Literatura sinalizada. Lembrando que o registro adequado para esse tipo de literatura produzida em uma língua de modalidade visoespacial, e não oral auditiva como as demais línguas, é por meio de gravação em vídeo. Com isso, o surgimento dessa tecnologia, aliada ao desenvolvimento da Língua de Sinais, possibilitou maior liberdade para o crescimento da Literatura Surda.

Dessa forma, atualmente, já é possível realizar a pesquisa proposta, pois ela encontra produções de textos sinalizados em vídeo. O corpus que será analisado de forma comparativa consiste em um dos tipos encontrados na Literatura Surda, a traduzida para a Libras, mais especificamente, os textos bíblicos traduzidos.

Por fim, o que nos intrigou durante todas as análises de produções textuais de cunho religioso foi: onde podemos encontrar uma parte do trabalho que demonstre ser categorizado e estruturado na Literatura Surda, da comunidade surda? Ou seja, nos textos religiosos em Libras, há dois tipos de textos Literário e Informativo? Para os textos em Libras, verifica-se apenas um ato tradutório enquanto os tradutores leem o texto religioso? São essas as questões que o artigo aborda na organização de categorias durante o desenvolvimento da pesquisa. 


\section{Fundamentação Teórica}

Geralmente a Literatura é transmitida de geração a geração a partir de conversas, narrativas, contos, músicas etc. e as pessoas adquirem essas obras literárias como parte de uma tradição cultural do seu povo no local que reside. Tal Literatura se faz presente no nosso cotidiano desde histórias narradas, de modo oral ou sinalizado, até as vastas adaptações tecnológicas publicadas em vídeos. Enfatizamos que a Literatura, de modo geral, possui vários conceitos e aspectos, os quais não serão tratados neste artigo, pois será apenas na literatura voltada para a comunidade surda - a Literatura Surda.

Visando melhor compreender um importante aspecto da comunidade surda - a Literatura Surda, antes de encaixar essa concepção com o texto religioso, serão discutidas as seguintes questões: como é a Literatura Surda? Seria a Libras a língua literária da comunidade surda?

Vemos que a Literatura Surda representa tanto a comunidade surda presente no território brasileiro quanto nos demais países. A parte mais interessante desse fato é que ela é composta do uso da língua de sinais no contato entre duas pessoas surdas sinalizantes. Peters (2000, p. 4) afirma que os surdos americanos não utilizam as histórias, inicialmente, na parte escrita e, sim, na ASL - American Sign Language ${ }^{2}$. Como podemos ver, a língua de sinais, assim como em qualquer lugar, possui sua comunicação interativa de forma visuoespacial, isto é, por meio da visão e do espaço; tal realidade aplica-se, também, à Libras, que é uma língua cuja característica

\footnotetext{
2 Língua de Sinais Americana.
} 
básica é o uso da visão e do espaço. Nas Línguas de Sinais, inclusive na Libras, as histórias são contadas de forma "oral”; é o que defende a autora acima, ao afirmar que os surdos norte-americanos, tecnicamente, são pessoas que expressar através da sinalização pelo contato pessoal o que na comunidade ouvinte significa as histórias.

No caso da pessoa surda, ela tem a sua tradição "visual” como "faceto-face communication ${ }^{3}$ ", que esclarece a diferença entre uma comunidade majoritária, formada por pessoas ouvintes e orientada pela audição, e que possui a tradição de produzir uma literatura de várias modalidades que vai da parte oral até a escrita, e uma comunidade minoritária, formada por pessoas Surdas que é orientada pela visão, a qual produz textos sinalizados e não escritos, tradição esta, que equivale à transmissão cultural pela “oralidade" (PETERS, 2000, p. 4).

Essa tradição denominada pela autora como "visual" ou "face-toface" enfrentou o risco de perder os textos sinalizados pertencentes à Literatura Surda, nesse caso, os textos religiosos. É por esse caminho que a cultura surda possui sua larga escala oral da cultura, isto é, uma cultura complexa que não pode ser desenvolvida por mera adaptação fácil para a literatura escrita.

Sutton-Spence $(2005$, p. 2$)$ relata $^{4}$ que

\footnotetext{
${ }^{3}$ Comunicação via face a face.

${ }^{4}$ Tradução do inglês: "Many signers are literate to some extent in the written form of at least one spoken language, but do not write their sign language because it is not a register of that language. This is a common situation for many of the world's minority languages, most of which have no written form, and it has considerable implications for the structure and function of sign languages and for the structure, composition and recording of sign language poetry, just as it does for any 'oral' unwritten language."
} 
Muitos sinalizantes são alfabetizados em certa medida, na forma escrita de pelo menos uma língua falada, mas não escrevem a sua língua de sinais porque não é um registro de língua. Esta é uma situação comum para muitas das línguas minoritárias do mundo, a maioria das quais não tem nenhuma forma de escrita, e tem implicações consideráveis para a estrutura e função das línguas de sinais e de estrutura, composição e gravação da poesia de língua de sinais, assim como ele faz para qualquer linguagem não escrita 'oral'.

Nesse sentido, é importante ressaltar o que Karnopp (2008) define sobre a concepção da Literatura Surda contemporânea; optamos por citá-la apenas de Literatura Surda:

A literatura surda tem uma tradição diferente, próxima a culturas que transmitem suas histórias oral e presencialmente. Ela se manifesta nas histórias contadas em sinais, mas o registro de histórias contadas no passado permanece na memória de algumas pessoas ou foram esquecidas. Assim, estamos privilegiando a literatura surda contemporânea, após o surgimento da tecnologia, da gravação de histórias através de fitas VHS, CD, DVD ou de textos impressos que apresentam imagens, fotos e/ou traduções para o português. O registro da literatura surda começou a ser possível principalmente a partir do reconhecimento da Libras e do desenvolvimento tecnológico, que possibilitaram formas visuais de registro dos sinais. (2008, p. 2).

Salientamos que a pessoa surda no tempo atual está vinculada à veracidade da informação suprida pela era da internet, ou seja, os surdos possuem seus conhecimentos atualizados pela internet e nas redes sociais, conforme Sutton-Spence et al. (2016):

No passado, antes do advento de novas tecnologias de registro filmado e dos meios de comunicação da internet, como Youtube, Facebook, por exemplo, era nos encontros face-aface das comunidades surdas que aconteciam os momentos de contação de histórias e outras performances artísticas em língua de sinais, que não eram registrados. Obviamente

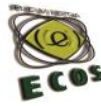


ficaram os registros na memória pessoal dos que tiveram a oportunidade de participar desses acontecimentos (2016, p. 86).

É de se esperar que as produções de textos em Libras das pessoas surdas estejam ligadas pelas redes sociais e pela internet. Nesse sentido, é necessário atentar para o fato de que a Literatura Surda permanece firme e sendo repassada.

Essas produções literárias por autores surdos são importantes para transmitir o conhecimento sobre a Cultura Surda com suas peculiaridades e características, além de ajudar os surdos a terem o reconhecimento, valorização, recuperação da autoestima e segurança, a fim de conseguirem conquistar o espaço literário e acadêmico que lhe é devido.

É importante ressaltar que a produção de texto sinalizado significa que as pessoas vão "ler" o texto pensado de uma maneira mais específica: o uso da Língua de Sinais, na forma de vídeo e/ou em escrita de sinais; isso fortalece o empoderamento da língua na comunidade surda e nos leva a um outro nível de compreensão mais profunda e complexa do que é um texto sinalizado com suas expressões afetivas pela Língua de Sinais.

Karnopp; Klein e Lunardi-Lazzarin, (2011, p. 21) comentam que:

As produções culturais de pessoas surdas envolvem, em geral, o uso de uma língua de sinais, o pertencimento a uma comunidade surda e o contato com pessoas ouvintes, sendo que esse contato linguístico e cultural pode proporcionar uma experiência bilíngue a essa comunidade. Nesse sentido, além da escrita da língua de sinais, a escrita da língua portuguesa também faz parte do mundo surdo, indispensável aos surdos brasileiros para a escolarização, a defesa dos seus interesses e cidadania. Pode-se pensar que o registro escrito em língua portuguesa favoreça a destruição da riqueza em sinais; mas esse registro, por si só, não é necessariamente um fator

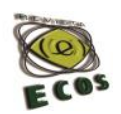


contrário, já que se pode pensar na escrita como a busca por tradução das raízes culturais.

Na citação das autoras, notamos dois pontos importantes em relação à produção de texto que nos leva a uma nova perspectiva em relação à comunidade surda. $\mathrm{O}$ primeiro ponto é a experiência bilíngue. Isto é, uma experiência da pessoa surda, ao trabalhar um texto, seja ela sinalizada seja escrita, demonstra a sua produção textual em língua de sinais sem restringir o uso da outra língua, no caso, a língua portuguesa, pois essa segunda língua é fundamental para que a pessoa que não é envolvida na comunidade surda possa compreender melhor as raízes, as ideias, as emoções da pessoa surda em seu texto original da língua de sinais.

Um outro ponto é a do registro escrito. Nesse caso é importante ressaltar que o registro escrito, a meu ver, na língua portuguesa, está associado à parte tradutória, pois é ela que fará a intermediação de uma língua de sinais para a língua portuguesa na modalidade escrita. Conforme as autoras relatam, o registro escrito é fundamental para relacionar as diferentes culturas em que a pessoa convive com a sua língua de origem.

A partir desse entendimento, ao nos voltarmos para o objeto de nosso estudo, percebemos que é necessário produzir mais textos que tenham referências bíblicas, ou seja, um aprofundamento textual da Bíblia em Libras que pode levar os surdos a uma outra produção cultural para que possam ter acesso ao conhecimento referente ao mundo espiritual e/ou divino. Ressaltamos que há registros de textos produzidos com itens religiosos como música, poesia e versos bíblicos encontrados nas redes sociais. 
Ademais, há outro tipo de produção cultural da comunidade surda: a escrita da língua de sinais, conforme sinalizam Karnopp; Klein e LunardiLazzarin, (2011, p. 21):

Além do registro das produções culturais de pessoas surdas através da escrita em língua de sinais e de traduções para a escrita da língua portuguesa, outras formas de documentação, como filmagens, são fundamentais para o registro das produções culturais que vão se perdendo ou se transformando. Para uma comunidade de surdos manter o leque de possibilidades artísticas e expressões da língua de sinais, os registros visuais são indispensáveis na criação de bibliotecas visuais, potencializados com a implementação de novas tecnologias da informação.

Assim, dizemos que, atualmente, há a tecnologia que favorece o uso dos vídeos, por meio dos quais a pessoa realiza filmagens, através da Libras, de forma espontânea e dinâmica. A partir dessa ideia de que a tecnologia de hoje vem contribuindo bastante, é que a comunidade surda tem se desenvolvido tanto na comunicação com o outro quanto na produção de textos traduzidos, adaptados ou criados pela própria comunidade surda.

Ressaltamos que um vídeo filmado em Libras também é um texto produzido e elaborado com a finalidade de transmitir ideias para a sociedade. Leite (2010, p. 5) defende que os vídeos produzidos em Libras também são outra forma de retratar uma produção textual:

Na superfície textual está aquilo que chamamos de forma da língua, isto é, aquilo que os nossos sentidos são capazes de captar: as palavras, expressões e frases que enxergamos, no caso da escrita ou das línguas de sinais, e as palavras, expressões e frases que ouvimos, no caso das línguas orais. A coesão textual, portanto, é realizada pela relação, ligação, conexão entre as palavras, expressões e frases de um texto. 
No entanto, é preciso compreender que a produção de texto não está relacionada apenas aos textos escritos, mas também à língua de sinais, em sua modalidade registrada em vídeo, ou em escrita de sinais. No entanto este trabalho apresenta apenas aqueles textos sinalizados registrados em vídeos.

\section{Categorização}

Essa parte visa apresentar quatro categorias relacionadas às produções de textos religiosos em Libras através de mídias digitais, trabalhados em vídeos para as redes sociais e/ou físicas como vídeos de internet e DVDs. As técnicas são elaboradas a partir de gravação de vídeo, divididas em parte até os estilos de apresentação, contida e escolhida em quatro categorias: figura, figurino, tradução da Bíblia e narrativa da Bíblia.

\section{Produção Literária com Figura}

Nesta categoria é utilizada o texto que contenha figuras durante a exibição do vídeo em Libras. A figura apresenta recortes do texto para a realidade de forma traduzida da Bíblia. As imagens são formadas de modo estático e dinâmico para representar personagens e cenários bíblicos.

A figura não é uma mera representação do real para o imaginário, ela também é representada por símbolos ou imagens. Como em qualquer língua, a imagem possui seus significantes e significados; de uma concepção mais visual relacionada à Libras, uma imagem vale mais, vai além de palavras descritas nela. Edgar-Hunt (2013, p. 24) aborda dois tipos de signos, imagens, que são baseadas no estudo da Semiótica: a física e a 
psicológica. A primeira parte, física, é um "signo como objeto", a coisa tangível que vemos ou “ouvimos", como uma placa na estrada, a lágrima da heroína ou as palavras "Vá em frente". Chama-se de "significante" um estímulo exterior. Já a segunda parte, a psicológica, é um “signo como conceito", a reação ao objeto, a ideia ou imagem mental que é provocada na mente da pessoa. Chama-se "significado" uma resposta interior ao significante.

Os surdos, ao assistirem um vídeo que contenha imagens, sentem maior facilidade de compreender o texto, seja traduzido ou não, pois as imagens nos adicionam informações que são fragmentadas, mas alinhadas ao texto final produzido.

Há outro ponto importante que os surdos conseguem produzir e/ou captar imagens durante a produção textual: a imagética da mente surda. Os surdos têm sua naturalidade de sinalizar imagens para descrever locais, objetos, pessoas etc. Supomos que uma pessoa surda aplica uma visão tridimensional na qual o enunciado monta, no ato de falar, "maquetes visuais invisíveis", quando relata localização de um certo ponto de referência do qual o receptor reconhece o referente. As imagens produzidas pelos enunciados das pessoas surdas por meio das línguas de sinas produzem um processo importante para a memorização da imagem invisível, mas com representação real. Segundo Santaella e Nöth (2015, p. 29), "a teoria imagética do pensamento mais radical vê, em imagens mentais, cópias icônicas da realidade", o que parece ser coerente com a produção de enunciados das pessoas surdas através, por exemplo, da Libras. 
É importante ressaltar que os surdos podem fazer a sua imaginação para imergir no entendimento da história da Bíblia na língua de sinais de origem.

\section{Produção Literária com Figurino}

O figurino é composto por representação das roupas, seja por épocas seja por estilos e formas diferentes, durante a apresentação de personagens. Tais apresentações são compostas por cenários com elementos e figurinos como itens adicionais na visualidade em Libras para que o receptor possa ter acesso a uma visão mais concreta do que já foi proposto por uma mera descrição reconstruída pelo que é dito. Essa categoria demonstra a importância do ator, seja ele surdo seja ouvinte, usuário da Libras, e este ser bem representado com o figurino de seu personagem para transmitir a essência do espetáculo religioso como algo sagrado; da mesma forma, devem estar bem representadas as vestes de épocas usadas, por exemplo, na reprodução de um ritual ou cerimônia religiosa.

O figurino constitui parte essencial da arte e, por meio dele, a arte ganha contornos estéticos que lhe são peculiares, os quais vão desde a robustez luxuosa representativa dos grandes impérios a um simples pano que pode se transformar em manto. A pessoa ao usar o figurino deve conhecer a história do personagem para se apropriar adequadamente da história que irá representar.

As roupas também envolvem o espectador, ao imaginar a vestimenta representada em época diferente. Roubine (2011, p. 59) nos traz melhor a compreensão do uso do figurino nas imagens:

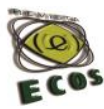


são estas possibilidades quase infinitas de alteração da imagem, de caracterização do personagem, que interessam à arte do ator. Não é que ele precise de roupas muito elaboradas. A rigor basta-lhe um traje cuidadosamente escolhido para suscitar, graças à "colaboração" do espectador, a realidade completa do personagem e seu modo de vestir. Mas esta definição elíptica e metonímica do figurino de teatro não equivale a uma recusa do figurino enquanto tal. Ela provém de uma escolha estética, da vontade de utilizar a capacidade de imaginação do espectador.

Por falar em figurino, este trabalho analisa o uso dele enquanto a pessoa sinaliza a Libras, pois a vestimenta também pode contribuir ou atrapalhar durante a sinalização. É preciso ter cautela, pois o figurino também é um item importante para representar a história da Bíblia. Nesse caso, vemos a utilização de técnicas para um preparo mais sistemático com as mãos, pela sinalização em Libras com a utilização de aspectos linguísticos como a expressão facial, corporal, topicalização, orientação das mãos etc.

\section{Produção Literária com Tradução}

Antes de iniciar a definição da tradução da Bíblia em Libras, precisamos mergulhar na tradução geral. Para compreender melhor o trabalho da tradução, é preciso conhecer bem o idioma de partida e o idioma de destino, ou seja, podemos definir que "é como a substituição de material textual numa língua por material textual equivalente noutra língua" (CATFORD, 1965 apud ROMÃO, 2010, p. 52). Assim, não se resolve uma tradução ao usar um dicionário, saber manusear programas de traduções automáticas ou algo semelhante; é necessário ter o sensus linguae de ambas 
línguas, isto é, conhecer melhor a língua e sua cultura, suas normas e sua literatura para poder traduzir a outra língua sem perder o conteúdo contido na língua.

Sobre a cronologia da tradução Konings (2003, p. 215) traz a breve história começando pela primeira "tradução completa da Bíblia em português e feita a partir dos originais [que] foi a de João Ferreira de Almeida (séc. XVII/ XVIII). Depois, os católicos se puseram a traduzir a Bíblia, primeiro com base na Vulgata de S. Jerônimo, depois com base nos originais".

Como se vê, a primeira obra traduzida brasileira tem a sua marca presente e importante para nós. É importante, no entanto, registrar que toda tradução tem seus traços traiçoeiros de uma língua para outra, assim como em qualquer língua traduzida.

E a tradução da Bíblia em Libras nos faz compreender que é necessário conter contextos referenciais de uma cultura para outra, pois a tradução transparece na cultura de origem.

\section{Produção Literária com Narrativa}

Seguindo a história original, no caso da Bíblia, os narradores possuem vastas histórias para contar e eles registram e padronizam suas narrações. Isto é, a pessoa que narra suas histórias, sejam clássicas sejam contemporâneas, acabam por inserir nelas traços de sua cultura, tornandolhes peculiares. É nesse caso que as narrativas possuem sua cultura adaptadas para o público-alvo, a pessoa com sua cultura adquirida. Nesse 
sentido, a narrativa depende de pessoa para pessoa, do vídeo para vídeo e de história para história.

A Bíblia possui diferentes interpretações que vão de entidades religiosas até a pessoa curiosa por história. Se há diferentes interpretações, há diferentes narrativas compreendidas. Há narrativa que segue a história original e outras que buscam trazer comparações existenciais para os dias de hoje. É importante ressaltar que a narrativa em Libras nos leva a um outro modo de representar histórias ao texto, pois sabemos que a pessoa surda, ao sinalizar, possui várias imagens que procura uma representação do real no qual se insere; no entanto, esse aspecto não constitui objeto de análise deste artigo.

$\mathrm{Na}$ narrativa visual, no caso, vídeo em Libras, o receptor pode ter o acesso dos artefatos característicos que competem diretamente com a narrativa literária da cultura surda. A cultura surda, no que concerne à literatura, também nos traz uma compreensão de que as histórias bíblicas narradas possuem traços distintos das histórias originais e estão sob influência de Libras.

É importante lembrar que a narração em Libras foca não somente a língua, mas também a textualização dela. Evidenciamos, assim, que os vídeos contados em Libras também são textos produzidos com narrativas voltadas para a comunidade surda. Essa narração varia de acordo com a composição de pessoas, dos textos bíblicos e do público-alvo. Barros (2010, p. 16) complementa que "a sintaxe narrativa deve ser pensada como um espetáculo que simula o fazer do homem que transforma o mundo”. 
Para entender a organização narrativa de um texto em Libras, portanto, podemos descrever o cenário - locais e paisagens, determinar personagens com suas características e traços culturais e o papel dela, os quais representam a história a ser contada. Novamente a narrativa possui mudança de estados, operada pelo fazer transformador de um sujeito que age no e sobre o mundo em busca dos valores investidos nos objetos. Da mesma forma, "as estruturas narrativas simulam, por conseguinte, tanto a história do homem em busca de valores ou à procura de sentido quanto a dos contratos e dos conflitos que marcam os relacionamentos humanos" (BARROS, 2010, p. 16).

Por fim, o que nos intriga durante todas as análises de produções textuais de cunho religioso é saber onde podemos encontrar uma parte do trabalho que demonstre o texto religioso de forma literária ou não. Nesse sentido, questionam-nos: a comunidade surda conseguiria distinguir esses textos religiosos? Seriam esses textos capazes de expressar textos religiosos em Libras assim como em qualquer língua? Há certas questões técnicas a esse respeito a serem abordados nos textos religiosos?

São essas as questões que o artigo aborda: os discernimentos dos textos religiosos Literários e Informativos encontrados durante o desenvolvimento da pesquisa.

\section{Metodologia}

A metodologia, além da pesquisa descritiva, tem como base a pesquisa qualitativa com suas análises bibliográficas. Embora o objeto de estudo desta pesquisa seja produções de textos de língua portuguesa 
brasileira para a Libras, os questionários servem como mais um complemento na coleta de dados e contribuiu para a análise dessas obras. Dos trechos de vídeos selecionados no Youtube ou em DVD`s em que há exibição de versículos da Bíblia em Libras, são doze textos sinalizantes ${ }^{5}$ que participaram como integrantes das gravações, para análise dos dados que detalha no item coleta de dados. O trabalho apresenta seis análises de versículos que contêm trechos bíblicos: Gênesis (GEN), Gálatas (GL), José do Egito (JS), Lucas (LC), Ouvindo a voz de Deus em Libras (OD) e Arca de Nóe (AN). Esses trechos foram retirados da Bíblia, de comunidades religiosas distintas, e de suas editoras próprias. Após as análises de tradução são formuladas as categorizações das produções literárias apresentando quatro tipos de categorias: a produção literária com figura; produção literária com figurino; produção literária com tradução e produção literária com narrativa. Após essa etapa, é descrita as discussões e observações fundamentais em relação à Libras com sua espacialidade e informações relacionadas à obra literária da Bíblia. $\mathrm{O}$ contato com os participantes foi realizado, inicialmente, por questionário devido à facilidade de esses contatos com os surdos se darem por meio de e-mail e rede social. Os questionários foram realizados com seus participantes surdos em seus respectivos estados: Distrito Federal, Goiás, Minas Gerais, Paraíba, Paraná, Pernambuco e Rio de Janeiro. Enfatizamos que todas essas localidades possuem (e os participantes frequentam) estabelecimento religioso

5 Aprovação do Comitê de Ética em Pesquisa, Centro de Ciências da Saúde da Universidade Federal da Paraíba-UFPB, número do projeto: 2.358.642.

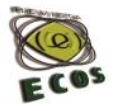


registrado. Destacar os textos religiosos categorizados para os tipos de textos Literários em Libras.

\section{Literários}

Nessa parte, abordaremos o que temos como foco desta pesquisa: categorização dos textos religiosos em vídeo em Literários ou Informativos. Nesse intuito, começaremos pelos textos religiosos literários, que são mais artísticos, com função estética, e objetivo recreativo, de modo a provocar diferentes emoções no leitor. Ressaltamos que quem assiste aos textos religiosos em vídeo tem a mesma função estética do leitor em Libras.

Nesse âmbito, é importante salientar que os textos literários nem sempre estão ligados à realidade dos dias de hoje (no caso da ficção), pois são subjetivos, e, dessa forma, podem apresentar diferentes interpretações de leitores distintos. Isso se dá, especialmente, porque o texto literário contém figuras de linguagem, sentido figurado e metafórico das palavras, o que torna o texto mais expressivo. Tais textos figuram-se divididos em cinco categorias: Figura, Figurino, Tradução e Narrativa.

\section{Figurino}

Esta é a categoria que foi a mais elogiada e prestigiada pelos entrevistados. Ademais, é a mais adequada para subcategorizar o texto religioso; assim, podemos afirmar que o Figurino é um texto religioso literário. Desse modo, como ele seria categorizado nesse contexto?

Primeiro, o texto religioso com produção de Figurino possui uma preocupação em elaborar sua estética de acordo com o tempo em que os 
personagens vivem. Além disso, transmite emoções em Libras, de maneira a cativar os entrevistados, dando maior ênfase ao sujeito representado no uso da Libras. Ressaltamos que as imagens cinematográficas são reproduzidas fielmente no imaginário da pessoa que "lê" esse texto religioso.

Os personagens do texto religioso utilizam a Libras como uma forma de reconhecer a importância do uso dela para a comunidade surda, mais especificamente para a pessoa surda, pois é primordialmente para ela que o texto religioso é destinado, embora não seja o único público a que se destinam tais textos.

(1):

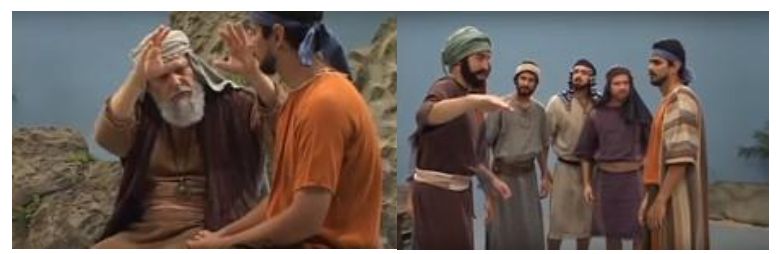

Fonte: https://www.youtube.com/watch?v=m2AT17oEdqM (2014)

Um dos pontos interessantes no momento da coleta do depoimento é que $02 \mathrm{E}^{6}$ relatou sua experiência reproduzida nesse texto como um modo diferente de trabalhar. Ele definiu o texto como um teatro, de modo a favorecer os estudos bíblicos, ao se utilizar o Figurino como exemplo a ser

${ }^{6}$ Nomes fictícios: os números e letras representam a quantidade dos entrevistadores divididos por categoria como, por exemplo: $\mathrm{A} 7$ = adventista do sétimo dia, $\mathrm{C}=$ católico, $\mathrm{E}$ = evangélico e $\mathrm{TJ}=$ testemunha de Jeová. Porém este trabalho apresenta as discussões coletadas por $\mathrm{E}$. 
seguido pelos outros textos religiosos que poderão surgir. Segue o relato do 02E:

02E: O teatro está para o surdo, como os livros estão para os ouvintes. Quanto melhor for o teatro, melhor será o aprendizado. Nos estudos de educação escolar, ficou provado que $70 \%$ do aprendizado vem das imagens. Então, para o surdo, o teatro é um excelente instrumento de aprendizagem bíblica. Porém, o bom teatro para surdos, precisa de acompanhamento de profissionais da área teatral, que ajudem cada figurino a incorporar melhor cada personagem... (Na minha cidade, foi feito isto com dois teatros surdos: a cidade inteira se divertiu com estas apresentações surdas. E por falta de 'verba', o trabalho foi descontinuado e os surdos perderam a motivação). Muito marcante o momento em que o rapaz José se atenta às instruções de seu pai Jacó. Foi profunda esta parte.

Notemos que ele diz que é "Muito marcante o momento em que o rapaz José se atenta às instruções de seu pai Jacó". Esse trecho significa que é um texto religioso de grande valia, segundo $02 \mathrm{E}$, pois reflete os momentos que enfrenta nos dias de hoje.

É importante definir que o Figurino é um texto literário, pois ele expressa emoções, diferentes realidades e funções estéticas. Entendemos, como Mourão (2016, p. 227) defende, que "os efeitos estéticos estão ligados à visualidade, pela visualiterária com características da identidade surda por meio da comunidade surda". Isso pode nos fazer inferir que o conteúdo do texto religioso literário busca atender a suas estéticas para melhor compreensão da comunidade surda. 


\section{Figura}

Essa categoria é a mais literária, por possuir texto religioso com estilo único voltado ao seu público-alvo. Consideramos essa parte como um texto religioso que busca expressar a linguagem adequada para a comunidade surda, sem perder o conteúdo buscado na Bíblia. Esse texto foi o segundo mais elogiado pelos entrevistados; eles alegaram que tal texto possui temas que abordam situações bíblicas contendo imagens e sua linguagem é destinada ao público-alvo.

(2):

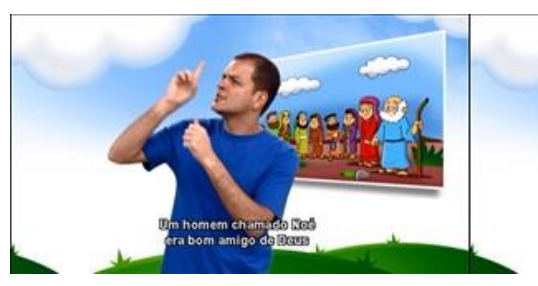

DEUS

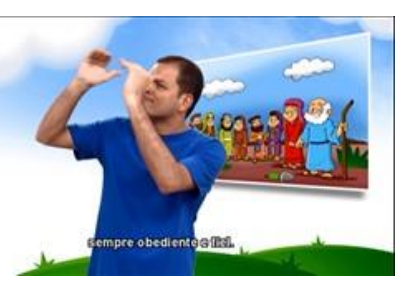

OBEDECER

Fonte: Aventuras da Bíblia em Libras: Noé. Instituto Expressão Surda. SSB, 2012.

O quadro (02) é um trabalho de texto religioso de vídeo voltado ao público infantil. Sobre o texto religioso Aventuras Infantis, o estilo dele segue de forma padronizada aos meios de tradução da Bíblia em língua de sinais para surdos. Além de exigir o uso da imagem com sua linguagem infantil, é importante abordar o uso de aspectos linguísticos e culturais da pessoa surda. 
(3):

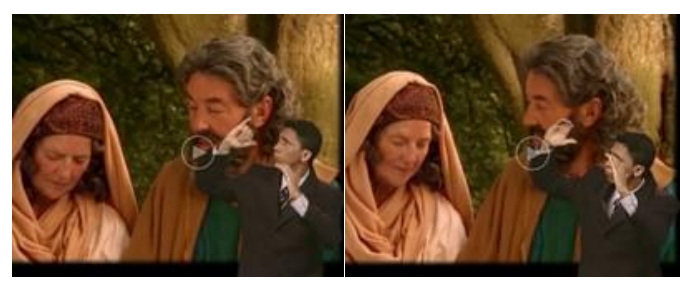

JEOVÁ OBEDECER

Fonte: https://www.jw.org/bzs/publicacoes/videos/Noé-Um-Homem-QueAndou-com-Deus/ (1997)

O quadro (03) possui o uso da imagem em vídeo, o que nos leva a categorizar este texto religioso. Ele possui linguagem própria, de versão adulta. Consideramos que o uso dos vídeos do texto religioso sobreposto em imagem de vídeo é favorável, já que as posições das imagens não interferem na visualidade do texto. Conforme o autor Edgar-Hunt (2013, p. 122) explicita, “a câmera só pode retratar o que está na frente dela, ou seja, o espaço na tela. Tecnicamente, a câmera não pode nos apresentar um espaço porque qualquer espaço na imagem é uma ilusão de enquadramento, iluminação e disposição de atores e cenário”.

Ainda é importante lembrar que o uso de imagens nos textos religiosos está associado ao imaginário do espectador, ou seja, "'a percepção visual atua recebendo informações sob a forma de textos, imagens, cores em termos de 'imagens mentais'. O seu registro é feito pela exploração do campo visual, conjugando a percepção global ou simultânea e a linear" (PLAZA, 2010, p. 52). 


\section{Tradução}

Essa terceira categoria é a da tradução. O único texto religioso em vídeo da categoria que é classificada como texto religioso literário, pois o tradutor expressou de forma literária suas emoções, fluidez, elementos fictícios de excelência. Esse texto atendeu às expectativas dos entrevistados por ser o texto religioso literário traduzido de melhor compreensão para a comunidade surda.

(4):

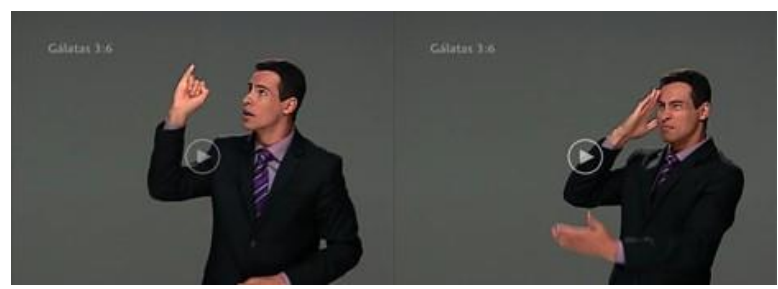

JEOVÁ

ACREDITAR

Fonte: https://www.jw.org/bzs/

Douettes (2015, p. 109) nos esclarece o seguinte sobre a tradução do texto religioso:

Isso é o trabalho do tradutor surdo, no processo tradutório em Línguas de Sinais. É possibilitado ao tradutor decidir quais os gêneros textuais, literários, dramáticos e líricos que possa traduzir e adaptar de uma cultura ouvinte para outra cultura surda. Em relação ao glossário de sinais-termos bíblicos desta pesquisa, são os gêneros literários que influenciam o tradutor com relação aos sinais-termos e definições em Libras, para a compreensão correta da mensagem do texto bíblico, também em acordo com a comunidade surda, que cria os novos sinaistermos bíblicos da Libras. Na Tradução Bíblica o tradutor/intérprete deve preocupar-se com o uso de princípios

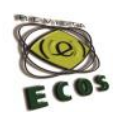


de tradução, linguísticos, teológicos e teóricos da comunicação, na exegese do texto-fonte.

Nesse caso, consideramos que, para trabalhar em um texto religioso em vídeo, é preciso ser bilíngue, conhecer duas línguas e suas culturas, com seus aspectos linguísticos e possuir estudos para se ter mais conhecimentos dos textos religiosos. Além disso, é necessário aplicar suas escolhas às técnicas de tradução, a fim de expressar melhor o conteúdo com suas passagens bíblicas de forma emocionante e cativante para o público surdo.

\section{Narrativa}

Esta categoria apresenta um texto semelhante ao da imagem, só que voltado a um texto religioso. Ela possui elementos estéticos que vão do uso dos personagens, histórias até às situações retiradas da Bíblia e incorporadas ao estilo narrativo, em certa parte do vídeo, pois o vídeo completo é de uma produção textual educativo e informativo, com elementos narrativos. Conforme Cândido (1976, p139-140) ressalta que a "literatura, por ser coletiva, requer certa comunhão de meios expressivos" determinados pela comunidade linguística. Esses elementos são caracterizados pelo texto religioso literário.

(5):

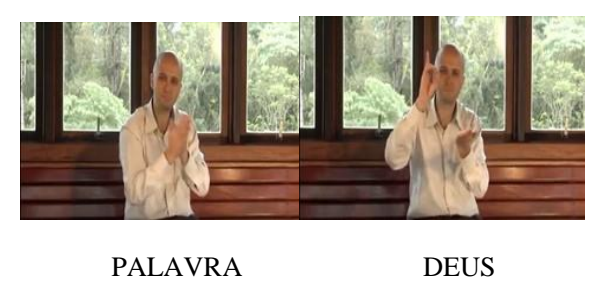

Fonte: https://www.youtube.com/watch?v=8fXO50plErE (2013)

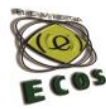


Notemos que o narrador do texto religioso possui traços literários incorporando personagens e descrevendo uma situação junto à expressão facial de serenidade. Segundo Carvalho (1981, p. 11), o "eu protagonista, a visão do narrador não é periférica: é central. Tem, entretanto, a desvantagem de ser fixa. O narrador-protagonista é um personagem que, por definição, é atuante, não podendo ser, ao mesmo tempo, espectador, crítico ou colecionador de opiniões alheias". Nesse texto religioso, há um personagem narrando, portanto, o texto é literário.

Outro ponto de elemento literário está no cenário, a natureza, a qual acrescenta tonalidade ao texto religioso, de modo que se possa assisti-lo de forma serena e pacífica. É nessa produção de texto religioso, de categoria narrativa, que se procura caracterizar o texto com seus elementos combinatórios junto ao personagem. De acordo com Edgar-Hunt (2013, p. 57), são três os aspectos dessa produção: Caracterização: ajuda as personagens a se tornarem reais para um público; Tempo: refere-se a personagens, cenários, ações; na verdade, todos os elementos da narrativa descritos anteriormente; e Focalização: posição final e crucial de um público.

Conforme descrito, o texto religioso narrativo possui características literárias e as retrata com clareza e emoção ao público surdo. Por fim, enfatizamos este estudo com a seguinte citação de Leite (1994, p. 12):

Essa proximidade pode nos dar a ilusão de que estamos diante de uma pessoa nos expondo diretamente seus pensamentos, quando, na verdade, tanto o NARRADOR como o leitor ao qual ele se dirige são seres ficcionais que se relacionam com 
os reais, através das convenções narrativas: da técnica, dos caracteres, do ambiente, do tempo, da linguagem.

\section{Informativos}

Embora haja textos extremamente ricos em recursos estéticos, como abordado na seção anterior, muitos textos bíblicos que fazem parte do corpus de análise são desprovidos de aspectos literários, configurando-se apenas como textos de caráter mais informativo, em que as características denotativas se sobrepõem às conotativas. Desta forma, não é porque o texto de uma narrativa bíblica está traduzido que ele ganha matizes literários. Em certas circunstâncias a tradução é levada para o âmbito apenas da informação, sem que haja os efeitos linguísticos e estéticos próprios do texto literário. Importante ressaltar que os informantes de nossa pesquisa, ao se depararem com esses textos revelam essa ausência de literariaedade nos textos, mas isto não implica que eles são ruins, mas apenas atendem a uma outra proposta, a informação, e não à estética. Propomos inserir na categoria, o termo não literário por informativo. Segundo Costa (2004, p. 17) reforça, a catalogação do literário e informativo "somente encontra justificação na carência de critérios teóricos claros e objetivos, capazes de responder à questão"; ainda assim, ela complementa que suas pesquisas são recentes e poucos discutidas no âmbito de literatura. Além disso Costa (2004, p. 18) ressalta que pesquisas

sobre o não literário são mais tardias do que as pesquisas sobre o literário. Uma grande convicção de que é possível definir literatura, enquanto fenômeno autónomo construído a partir de um uso específico da língua, marcou a primeira metade do século XX, envolvendo as correntes mais influentes de Teoria e Crítica Literária e da Linguística. O não literário confinava- 
se, nesta perspectiva, a uma categoria residual. As reflexões sobre o não literário vão surgindo sobretudo a partir dos anos [1970].

A definição do não literário é categorizada por Costa (2004, p.17) de "banda desenhada aos textos jornalísticos (notícia, reportagem, entrevista), slogans publicitários, cartas, atas, requerimentos, currículos, relatórios". Percebemos que a mesma autora complementa a descrição dela, ao demonstrar que há falta de elementos literários nela: "menos criatividade e menos elaboração linguística, literária e estética, e também textos cujos modos de produção, distribuição, divulgação, circulação e consumo se distanciam dos da literatura" (2004, p. 17).

No mais, podemos definir que o texto não literário possui certos critérios semelhantes ao do literário que podem ser categorizadas de modo geral: "institucionais, literários, linguísticos, pragmáticos e sociais" (COSTA, 2004, p. 17).

Intentamos demonstrar que o texto religioso analisado possui categorias divididas nesse tópico. Desse modo, ao analisarmos os depoimentos dos entrevistados, encontramos vários pontos negativos, no entanto isso não significa que o texto religioso seja ruim, mas que ele pode nos remeter a uma nova proposta que apresentaremos na sequência. Nesse contexto, podemos afirmar que o texto informativo pode ser encaixado como um texto que tem como objetivo informar, esclarecer, explicar, ou seja, pretende ser útil ao leitor. Ele pode ser definido como um texto informativo, no caso da Libras, com especificidades e linguagens esclarecidas e objetivas. 
Ao voltarmos para a proposta da pesquisa, que tem como foco a Libras, demonstramos como seria o texto religioso com sua adaptação, com o encaixe da parte teórica para os elementos visuais que os vídeos repassam, ou seja, um "texto informativo" sem apresentar os elementos de emoções, estéticas e linguagem.

\section{Tradução}

Passemos à categoria Tradução, mas de abordagem não literária. É interessante pensar que, geralmente, o trabalho tradutório por parte da escrita em geral possui caracteres literários, porém, na Libras, desnorteia-se o caminho para um outro olhar: a do texto religioso de Tradução, o qual está na categoria de Informativo. Para tratar desse aspecto, destacaremos os depoimentos de alguns entrevistados, mais especificamente voltados ao texto religioso traduzido de Gálatas, em duas versões, e de Lucas.

(6):

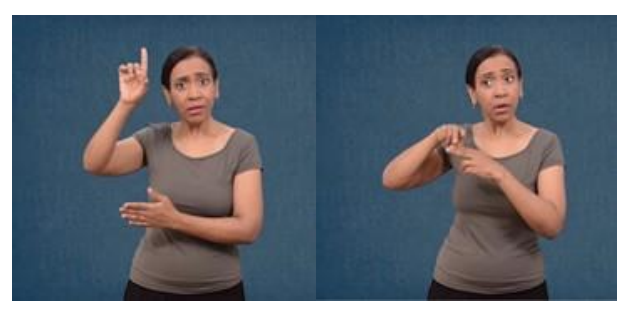

DEUS

POR ISSO

Fonte: A Bíblia em Libras: Carta de Paulo aos Gálatas. Criado produzido e editado por Marilia e Gilmar Manhães. Rio de Janeiro - RJ, 1999.

Mais uma vez, retornamos ao texto religioso Informativo de categoria Tradução. Verificamos que o vídeo produzido por Marília e 
Gilmar Manhães possui características apenas voltadas para a produção de materiais de consumo, informativos, menos literários e de circulação. Mas isso não quer dizer que o texto religioso é o menos favorável à comunidade surda. É preciso lembrar que o texto religioso informativo possui função de repassar informações reais, associar o mundo real do espectador, não possuir elementos fictícios, porém, na versão de vídeo em Libras, podemos pensar que o informativo está associado à falta de nitidez visual, clareza da informação e de aspectos linguísticos. A única função semelhante do texto informativo entre duas línguas, do português e da Libras, é a de transmissão de informação do conteúdo.

Os depoimentos que seguem nos guiam ao texto religioso informativo. Primeiramente, trataremos da função de transmissão de informação, verificada no depoimento de 02E:

02E: Esta Marília Manhães, até onde eu sei, é uma missionária. Então, ela se dedica à transmissão da Palavra de Deus (...) ela está ciente que a mensagem transmitida vai tocar muitos surdos. (...). Na minha opinião, este vídeo é uma transmissão de conhecimento. Se ela estivesse 'pregando'. Tenho certeza, que as emoções estariam muito mais evidentes, seus sinais seriam mais firmes, suas expressões faciais mais destacadas, etc.

02E reforça que o texto religioso está apenas exercendo a função de transmissão de conteúdo. Isto é, o texto religioso de Tradução dos Manhães é um texto informativo, embora seja traduzido da Bíblia em língua portuguesa para a Libras. O participante da pesquisa 02E diz que, se ela estivesse 'pregando', teria mais emoção. Esse comentário nos leva a pensar 
que as emoções estão associadas ao outro texto religioso literário, o que não é demonstrado nesse texto religioso.

O depoimento de $03 \mathrm{E}$ aponta para o fato de que o texto religioso não possui estética literária, referindo-se, para o caso, à clareza da informação. Nesse ponto, ressaltamos a necessidade de inserir os versículos na tradução da mensagem, de acordo com que afirma 03E, para podermos analisar quais etapas e/ou fatos ocorrem no texto religioso, como também na Bíblia, na parte escrita. Veja o depoimento abaixo:

03E traduzido de vídeo: [...]. Não sei se já expliquei antes, se o vídeo for todo sinalizado, de capítulo 3:1-14, os surdos vão se confundir em quais versículos ao ler a Bíblia em português. As vezes não sabem quais palavras que está no versículo. Deveria buscar estratégias assim, por exemplo, na sinalização Gálatas 3-8, precisa aparecer os números do versículo no canto superior esquerdo do vídeo. E as pausas serviriam para terminar o versículo e partir para o próximo versículo e por assim diante. É desse jeito que precisa ser acrescentado no vídeo assim como o vídeo de TJ.

Há outro depoimento que contribui na pesquisa, ao se afirmar que o mesmo texto religioso não possui melhor desempenho literário; assim, há a necessidade de se possuir aspectos linguísticos explorados no texto religioso. Esse ponto é crucial. Entendemos que o texto religioso de Tradução deveria trabalhar na exploração de suas especificidades, com o fim de produzir elementos visuais e literários. Isso nos faz confirmar o fato de que o trabalho de tradução com texto religioso precisa estar ligado a um melhor desempenho linguístico da Libras, ou seja, faz-se necessário transformar o texto religioso de tradução informativo para o literário. Nesse sentido, realizamos uma questão que remetesse o entrevistado ao uso de texto religioso como material de estudo bíblico, sem que esse fosse

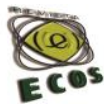


consultado em português. Para nossa surpresa, os entrevistados

responderam de forma negativa, justificando, de acordo com os depoimentos, a falta de clareza da informação, nitidez visual e aspectos linguísticos da Libras. Confiramos os depoimentos abaixo:

01E traduzido de vídeo: E é preciso que seja um surdo no lugar dela, que tenha estudos bíblicos e de tradução para que possa traduzir com qualidade expressando sua identidade e cultura surda com aspectos linguísticos da Libras como o uso de referências espaciais e expressões faciais que é fundamental, [...] é o que falta no vídeo, pela M. [...] Outra parte que me deixou intrigado é na frase que ela usa 'confiar pronto só obedecer Lei perde Deus castiga', dessa forma faltou a essência da informação, detalhadamente no verso da Bíblia adaptando para Libras de forma exposta. Não pode acrescentar muito alargando o texto que não está contido na Bíblia. [...]. É preciso de mais estudos para poder traduzir de um versículo de forma nítida para os surdos compreenderem melhor. Se os surdos tiverem suas dúvidas, mesmo que a sinalização esteja nítida, eles vão estudar mais a Bíblia, em português, assim como ouvintes que o lerem o português, vão estudar e pesquisar para poder compreender. Há estudos bíblicos para isso. Pois é preciso separar os complementos que ela usou e o vídeo precisa estar ao mesmo nível da Bíblia.

08E traduzido de vídeo: Falta-me nela os estudos e adaptações com seus aspectos referenciais espaciais comparando o do TJ, esse segundo é realmente uma adaptação com seus aspectos linguísticos atendidos, o que me fez compreender de forma clara. Aquele vídeo pode substituir, sem precisar ler a Bíblia em português. $O$ da Marilia, na minha opinião, não tem como substituir. [...] Caso eu não lesse em português, certeza de que eu não compreenderia, pois ela não usou os aspectos referenciais espaciais da Libras.

Depois de ter organizado os depoimentos dos entrevistados, constatamos que há outro ponto crucial no papel do tradutor, não muito

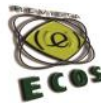


abordado neste artigo, mas fundamental nas análises. O tradutor precisa incorporar o papel de narrador, personagem etc., pois é um dos elementos importantes no momento do traduzir. Para isso, é preciso transformar o tradutor/intérprete em ator, narrador, apresentador. Veja o depoimento de 08E:

08E traduzido de vídeo: Ao ler e entender Gálatas em português, capítulo 3:6-8 para associar ao vídeo, da Marilia, eu compreendi razoavelmente, mesmo sob ajuda da leitura. (...). Apenas exercendo o papel de intérprete, não de apresentador, de ator, que estuda o texto para poder expressar melhor e adaptar pra Libras. Ela não o fez, apenas de intérprete ouvindo o texto e traduzindo para Libras, de forma imóvel. Pois compreendi razoavelmente. Não ler a Bíblia em português e compreender apenas o vídeo como texto substituindo-o?

Nesse sentido, reforçamos o entendimento de que é preciso elaborar um texto religioso com as especificidades sugeridas pelos entrevistados. Há outros pontos, no entanto, a serem discutidos posteriormente. Um desses foi relatado por um entrevistado, com bastante experiência no trabalho de tradução, ao dizer que o intérprete deveria repensar, no momento do estudo de texto religioso, qual a técnica que melhor se aplica no momento da tradução. Segue o depoimento 01E:

01E traduzido de vídeo: Vejo outro sinal que complementou 'porque é lei' e 'acreditar Jesus', mas neste caso o versículo diz o nome Jesus? É claro que pode, na Bíblia, fazer uma tradução correta e boa, mas é preciso complementar por exemplo, a fé, Deus, Ele me aceita, Crê em Jesus, etc. Poderia ter uma aplicação ou estudo bíblico, estudar melhor para poder compreender a Bíblia. Se o surdo assistir e tiver dúvida, ele mesmo pode estudar a Bíblia de forma separada. No entanto, a aplicação precisa ser de forma separada do vídeo assim como glossários em sinais. Um exemplo disso é a palavra 'gentio', ela usa o sinal 'não-é-judeu', será que não

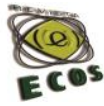


tem o sinal para essa palavra? Eu sei o que significa, mas no vídeo não é identificado como gentio e sim não é judeu. Os surdos veriam como não judeu, pois o vídeo parece sinalizar sobrepondo os conceitos defasados com sinalização seguida do português.

(7):

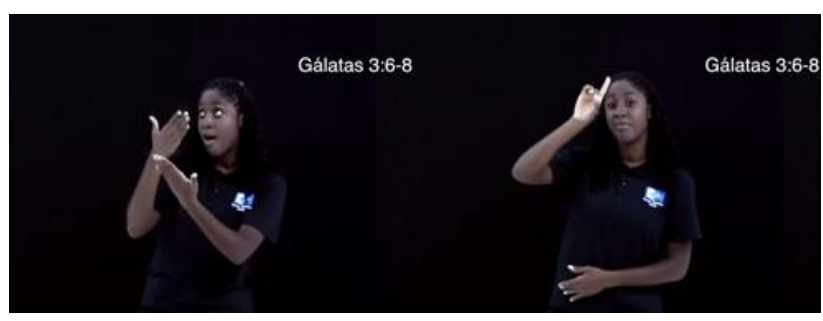

ACREDITAR

DEUS

Fonte: https://www.youtube.com/watch?v=yk3FONBlpOY (2015)

Esse texto religioso representa claramente um texto informativo, já que nele há uma comparação de nitidez nas informações e de estéticas visuais. Os entrevistados, pelo que conferimos nas análises, definiram esse texto religioso como um texto sem adequação visual. Isto é, para ter o melhor trabalho de texto religioso, é preciso possuir recursos técnicos e alteração da vestimenta para que se possa enxergar melhor o trabalho textual. Finalizamos com o depoimento de 03E, que, resumidamente, fez uma análise comparativa dos textos religiosos:

03E traduzido de vídeo: há uma mulher de blusa preta com o fundo preto e ainda a pele negra o que gerou um visual ruim. E atrapalhou. No segundo vídeo, TJ, possui ótima visualização com o fundo adequado. Porem há dois pontos: notei que, nos versículos 6,7 e 8, o primeiro vídeo (Adventista) foram bastante reduzidos, omitindo-os. Já no do

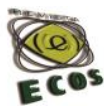


TJ demonstrou toda explicação. Eé claro que os dois possuem suas diferenças: no TJ sinaliza de forma básica com clareza adequando ao tipo de público surdo de modo geral. No entanto, eu defino o vídeo de TJ com explicações dos versículos 6, 7 e 8 de forma perfeita e detalhada. Já que o primeiro vídeo, da mulher negra, foi omitida.

De fato, há recursos que necessitam ser inseridos no texto religioso, pois são uma forma de demonstrar que o texto possui preocupação em manter uma função estética, a fim de oferecer melhor leitura ao espectador.

(8):

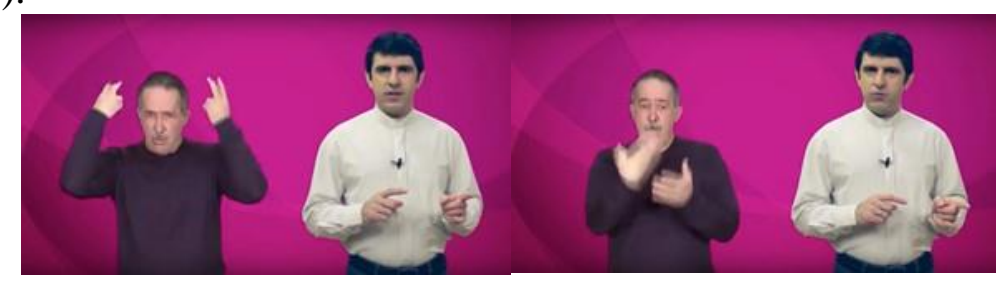

OVELHA

PERDIDA

Fonte: https://www.youtube.com/watch?v=aFmeos YeN2A (2013)

$\mathrm{Na}$ continuidade da análise, confirmamos que esse texto religioso possui as mesmas características que as de texto informativo, em razão do que colhemos nos depoimentos expostos pelos entrevistados, quando eles dizem que o problema real do texto religioso está na estética do tradutor e da Libras. Nesse sentido, os depoentes elencaram os seguintes problemas: a posição de duas pessoas juntas, falando e sinalizando; as vestimentas inadequadas sob contraste dos dois locutores; o fundo rosa que não favorece a leitura; estruturas linguísticas escassas, o torna a Libras sinalizada 
semelhante à estrutura gramatical do português; e, por fim, o fato de não apresentar elementos emocionantes.

Esse é o caso que o trabalho apresenta os resultados obtidos nas análises realizadas. Finalizamos o trabalho apresentando propostas que têm toda a condição de serem realizadas. No mais, já evidenciamos que os textos religiosos em vídeo possuem um tratamento diferenciado por conta de diversas doutrinas e diferentes produções técnicas de tradução, além de diferentes versões de textos bíblicos.

\section{Considerações finais}

Nesta investigação, partimos da curiosidade para saber como seriam os tipos de textos religiosos existentes nos vídeos feitos em Libras. Entendemos que, para isso, é impossível ter alguma conclusão a respeito, sem ao menos analisar os textos religiosos encontrados. Dizemos mais, de forma a enfatizar o que pesquisamos, sem texto religioso em Libras, que não haveria material a ser abordado nesta pesquisa.

Com esse entendimento, o artigo enfatiza trabalhar, nas obras encontradas, a associação dos textos religiosos aos da Literatura Surda, com o fim de categorizá-los em Literários e Informativos. As análises efetivadas levam a concluir que existem vários pontos que precisam ser discutidos futuramente em outros trabalhos. De modo geral, a pesquisa ressalta que o texto religioso é muito importante para qualquer pessoa envolvida em sua religiosidade, em qualquer língua existente. Porém, quando abordamos um texto religioso em vídeo, questionamo-nos: é possível imaginar que a comunidade surda escolheria uma língua, a Libras, sem ao menos consultar 
a língua portuguesa, para a compreensão em definitivo de uma Bíblia, a qual irá afetar e conduzir a pessoa ao seu desenvolvimento espiritual?

Observamos, durante o percurso investigativo, que os entrevistados se preocupam com os sinais exibidos no texto religioso. Durante as respostas, notamos que eles também demonstram preocupação com a estética do sinalizador, com a visualidade do texto religioso, a fim de "corrigir" para melhor o desempenho linguístico; assim, os entrevistados assistiram aos vídeos e, ao mesmo tempo, analisaram os aspectos linguísticos e visuais que estavam ausentes no texto religioso. Tal fato nos leva a compreender que a preocupação dos participantes da pesquisa está na estética do texto religioso, e não no texto propriamente dito: a Bíblia ou outro texto religioso presente nos vídeos exibidos.

Pelo direcionamento dado à pesquisa, identificamos que há dois tipos de textos religiosos, os quais foram analisados e categorizados: texto religioso Literário e texto religioso Informativo. No texto Literário, encontramos as seguintes categorias de Produção textual com: Figura; Figurino; Tradução e Narrativa.

Para a categoria Figurino, compreendemos que se trata do texto religioso Literário definitivo da comunidade surda. Os entrevistados apresentaram depoimentos positivos nesse texto religioso Literário, pois demonstraram certa afetividade pelo uso dos figurinos e dos personagens que sinalizavam os textos. Assim, mesmo que não houvesse diálogo em certos versículos analisados da Bíblia, eram reproduzidas fielmente as situações, e, assim, o texto emergiu no imaginário da pessoa surda. Isso nos leva a entender que o texto religioso Literário Figurino é o mais adequado 
para a comunidade surda, principalmente para os surdos, por conter certas emoções, estéticas e o imaginário característico da Bíblia para um texto religioso Literário.

Há outros aspectos que são de suma importância para a comunidade surda, por conterem elementos visuais que mais contribuem para o texto religioso Literário: a Figura. Sabemos que o sinalizador, sozinho, expressase de todas as formas, a fim de trazer melhor compreensão para o que o texto religioso da Bíblia passa; porém, sem a imagem, o espectador sente dificuldade de entendimento, ao não identificar quais elementos simbólicos o texto religioso intende demonstrar. Foi nesse contexto que compreendemos, ao analisarmos os depoimentos e o texto religioso, a necessidade de associação entre o que foi dito e o que foi visualizado, de forma que se apresente uma nova abordagem que carece de atenção: o texto religioso Literário Figura. Nesse sentido, ressaltamos que a imagem exibida no texto religioso não é um adicional, mas uma contribuição imagética que expressa a situação, tida, ao mesmo tempo, como real e fictícia. Assim, defendemos que os personagens, as geologias e os elementos associados à divindade necessitam de adição ao texto religioso, seja ela em fotos seja em desenhos e/ou vídeos.

O texto religioso Literário de Tradução pôde ser observado, nas análises realizadas, como um texto emotivo que expressa as palavras que são proferidas na Bíblia. Esse é mais um caso que preocupa em muitos estudos de traduções; assim, deve-se dar atenção às estéticas, aos elementos espaciais, à visualidade e aos aspectos linguísticos, sem que se fuja da essência do conteúdo transformado de uma língua para outra: a atratividade 
conceitual do texto religioso. $\mathrm{Na}$ tradução de um texto religioso, é comum encontrarmos vestígios religiosos de diferentes entidades e doutrinas, por conta dos léxicos que os identificam em grupos religiosos. Foi nesse contexto que notamos no texto religioso literário Tradução os vestígios que encantam, transmitem e apresentam estéticas únicas no texto.

Em relação à Narrativa, confirmamos que ela possui especificidades essenciais no texto religioso: as incorporações do sinalizante diante da narrativa que misturam o personagem, a divindade, o narrador etc. à história, de forma a se ter o espaço visual e suas referências fortemente utilizados no texto religioso. Esses elementos linguísticos são mais frequentes no momento em que o texto religioso Literário Narrativa é apresentado. É importante ressaltar que as narrativas da Libras buscam a força da visualidade com elementos estéticos que atraem os olhares da comunidade surda.

Por fim, abordamos o texto religioso Informativo de Tradução, a única categoria encontrada na investigação. O texto Informativo de Tradução não possui preocupações estéticas e emocionais, ele é apenas usado como fonte ou transmissão de informação à pessoa surda, assim como acontece em muitos textos religiosos que podem ser analisados futuramente. O texto religioso Informativo de Tradução nos fez pensar em outra proposta que pode contribuir para a comunidade surda, mais especificamente para a área de tradução e interpretação de Libras e Língua Portuguesa.

Pela pesquisa, entendemos que os textos religiosos possuem categorias tais empreendidas e encontradas na investigação, o que atendeu ao objetivo previsto. Nesse sentido, podemos afirmar que as categorias 
ajudam a organizar e a catalogar os textos religiosos, sejam eles Literários ou Informativos, pois, sem elas, fica difícil identificar tal classificação. Vale ressaltar, nesse intento, que outras literaturas existentes, que vão de piadas ao estilo poético, já possuem categorias organizadas. O uso delas está associado ao da Literatura Surda, isto é, ao "da arte de sinalizar, [por meio de] um conjunto de processos de significados estéticos, ficcionais, frasais sinalizados e/ou palavras, formando um processo de identidade, cultura e língua, a partir da experiência” (MOURÃO, 2011, p. 227).

Por fim, é importante ressaltar que os textos religiosos em Libras estão inseridos na Literatura Surda. Esses trabalhos de textos religiosos categorizados irão contribuir muito para que a identificação comunidade surda com a religiosidade. É importante dizer que essa identificação do usuário da Libras com o texto religioso na Literatura Surda faz parte da experiência vivida na Libras com a comunidade surda, ou seja, o texto religioso em Libras traz um vínculo inquebrável entre a divindade religiosa e a experiência linguística da pessoa surda.

\section{Referências}

BARROS, D. Teoria Semiótica do Texto. 4. edição. São Paulo: Ática, 2010. CÂNDIDO, A.; ROSENFELD, A. A Personagem de Ficção. Ed. Perspectiva, 1976.

CARVALHO, A. L. C. Foco narrativo e fluxo da consciência: questões de teoria literária. São Paulo: Pioneira, 1981.

COSTA, M. do R. O texto não literário na aula de língua materna: perspectivas de abordagem didáctica do anúncio publicitário impresso. 
2004, 262 f. Dissertação (Mestrado em Linguística e Ensino da Língua). Faculdade de Letras da Universidade do Porto, Portugal, 2004.

DOUETTES, B. B. A tradução na criação de sinais-termos religiosos em LIBRAS e uma proposta para organização de glossário terminológico semibilíngue. 2015, 440 f. Dissertação (Mestrado em Tradução). Centro de Comunicação e Expressão, Universidade Federal de Santa Catarina, Florianópolis, 2015.

EDGAR-HUNT, R; MARLAND, J; RAWLE, S. A linguagem do cinema. Tradução: Francine Facchin Esteves, Scientific Linguagem Ltda; revisão técnica: Sérgio Nesteriuk. Porto Alegre: Bookman, 2013.

KARNOPP, L. Literatura Surda. UFSC: Florianópolis, 2008.

Produções culturais de surdos: análise da literatura surda. Cadernos de Educação: FaE/PPGE/UFPel. Pelotas, n. 36, p.15-174, maio/agosto, 2010.

KARNOPP, L; KLEIN, M; LUNARDI-LAZZARIN, M. (Org). Cultura Surda na contemporaneidade: negociações, intercorrências e provocações. Canoas: ULBRA, 2011.

KONINGS, J. Tradução e Traduções da Bíblia no Brasil. Perspectiva Teológica. v. 35, n. 96, 2003.

LEITE, T. de A. Leitura e Produção de textos. Florianópolis: UFSC, 2010. LEITE, L. C. M. O foco narrativo, 7. ed. São Paulo: Ática, 1994.

MOURÃO, C. H. N. Literatura Surda: Produções Culturais de Surdos em Língua de Sinais. 2011, 132 f. Dissertação (Mestrado em Educação). Faculdade de Educação, Universidade Federal do Rio Grande do Sul, Porto Alegre. 2011. 
Literatura Surda: experiência das mãos literárias. 2016, 287 f.

Tese (Doutorado em Educação). Faculdade de Educação, Universidade Federal do Rio Grande do Sul, Porto Alegre, 2016.

PETERS, C. Deaf American Literature From Carnival to the Canon.

Washington, D.C. Gallaudet University Press, 2000.

PLAZA, J. Tradução intersemiótica. 2 ed. São Paulo: Perspectiva, 2010.

ROMÃO, T. Ilusão teatral versus realidade tradutória: os extremos da tradução teatral. In: LÚCIO, A. C; SCHNEIDER, L. Cultura e Tradução: interfaces entre teoria e prática. João Pessoa: Ideia, 2010.

ROUBINE, J. A arte do ator. 2 · edição, Tradução: Yan Michalski e Rosyane Trotta. Rio de Janeiro: Zahar, 2011.

SANTAELLA, L; NÖTH, W. Imagem: cognição, semiótica, mídia. 1. ed., São Paulo: Iluminuras, 1997 - 9 reimpressões, 2015.

SUTTON-SPENCE, R; LADD, P; RUDD, G. Analysing Sign Language Poetry. Palgrave Macmillan, 2005.

SUTTON-SPENCE, R; FELICIO, M; LEITE, T; LOPES, B; MACHADO, F; BOLDO, J; CARVALHO, D. Os craques da Libras: a importância de um festival de folclore sinalizado. Revista Sinalizar, v. 1, p. 78-92, 2016. 